\title{
THE EDUCATIONAL ROLE OF EVALUATION: FORMATIVE AND SHARED EVALUATION IN THE UNIVERSITY FIELD
}

\author{
María Isabel Alba Dorado \\ Departamento de Arte y Arquitectura, Universidad de Málaga, Campus de Excelencia \\ Internacional Andalucía Tech (SPAIN)
}

\begin{abstract}
Nowadays, we have a scenario marked by an increasingly complex and time-consuming formative model, which differs considerably from that which has been used until now. This raises the need to rethink, review and reconsider the teaching and learning model of today's universities with the aim of designing a new educational model that responds to the new emerging training needs that early twenty-first century society demands.

These changes in the training model make it necessary to rethink the existing evaluation processes, which are going to be affected by strong changes. They are determined not only by the passage of the traditional emphasis put on the teacher and the education, to the importance that is given today to the lea rning and to the student as the centre of this learning process; but it also changes the purpose of evaluation, moving from the acquisition of a series of academic knowledge to the development of skills and gaining basic and more complex applied knowledge; but above all, it changes the role that evaluation has in improving these learning processes.
\end{abstract}

The usefulness of the evaluation is not only in the ability that it gives us to verify the final performance of the student's learning, but that it should also serve as a training element, which is integrated into the teaching and learning processes from start to finish. Thus, the evaluation should serve not only to assess whether the student has assimilated knowledge, but also to guide their learning.

This in-depth review of the evaluation process also involves thinking about the method and the actors involved in this process. So, against the punitive nature of traditional assessment carried out by the teacher who evaluates a group of students in an exercise of authority, it is necessary to think of alternatives that involve and engage students in their own evaluation process and, therefore, in their own training in order to achieve a lasting learning that will serve them throughout life.

In this new evaluation model, the actor who assesses is not only the teacher, but all those involved have a responsibility to participate in the evaluation and self-assessment activities. In this way, evaluating is a shared responsibility, in which neither the teaching nor the learning are stopped. The student must participate in all activities to keep learning.

Thus, the evaluation should be understood as a formative and shared activity between teachers and students. This will allow us to definitively know whether or not the teaching objectives, methodology used, resources, assessment, etc. are responding as expected or whether they have to be changed in time to get closer to the fixed goals. All this leads us to consider and to take into account in the process of teaching and learning not only the more technical aspect of evaluation, but also its more human, critical, reflective, formative and negotiating dimension.

Keywords: Formative evaluation, shared evaluation, self-assessment.

\section{INTRODUCTION}

\subsection{New challenges for university teaching}

Nowadays we are living in a globalized world, characterized by its rapid momentum, and a knowledge society in continuous evolution with multiple tools of access to information, which requires professionals with new skills and abilities.

This situation opens a scenario marked by a formation model increasingly complex and extensive in time, which differs considerably from that has been done so far and that makes necessary to rethink the University. Teaching in our universities must inevitably be positioned in front of the new approaches, benefits and considerations that society demands for the XXI century. For this reason, it is necessary to define strategies and continuous reflection mechanisms that take it to adapt to new 
changing situations and to do so also from the quality and excellence. This is one of the great challenges for our universities [1]. These changes affect both students and university teachers.

For this purpose it is necessary to define new strategies and mechanisms for reflection in line with the expectations of the degree and postgraduate. It is required to review the teaching model of current universities, reconsidering the forms of teaching and learning, not only according to which have you wanted to teach, but also to how you will teach. The objective is to move from the traditional model of transmission of knowledge from teacher to student, in an area in which the educational institution is considered as the only channel of knowledge, to a model based on the development of skills in the student. This makes that it becomes a true protagonist of their own formation. The student should be able to learn and build a meaningful and contextualized knowledge [2], [3] y [4]. In this way, knowledge ceases to be stable and poor to demand its enlargement and update constantly throughout life. The school loses its exclusivity in transmitting knowledge and information.

All this represents a significant change from the way that, so far, had governed the traditional university teaching. The university is facing a profound change opportunity [5] that should be leveraged to identify, design and develop skills that allows to educate critically and reflectively, the professionals of the future.

\subsection{New training models}

This change in the educational model is necessary to rethink the role of the student, which has to participate much more actively in the process of learning what he does today, so take the students to achieve the ability to acquire all those knowledge, skills and attitudes that will require throughout their life in their academic or professional training. In short, learning to learn.

In addition, arises the need to define an educational model that goes beyond undergraduate degrees, postgraduate and doctoral programs, prompting the development of a continuous, comprehensive, flexible, innovative training and effective in response to new emerging training needs that society from the beginning of the 21st century demands.

This continuous training throughout the life (Life Long Learning) implies the need to develop new educational strategies aimed at creating learning situations. It would be, therefore, a teaching oriented more to show an attitude, facilitate, encourage and stimulate autonomous learning, motivating and encouraging students and urging them to learn to learn. As expressed Teodoro de Anasagasti [6], "it is not the best teacher the one that most clarifies concepts, the one who more solid truths says. That best should be kept is that teaches to observe, to inquire; which encourages the research; he lectures to fend for oneself; which operates the personality; which planting the interest, the desire of improvement, the concern".

This makes it necessary to define more flexible learning pathways, supporting lifelong learning from the earliest stages, especially for a knowledge that is no longer stable to demand its expansion and updating steadily over time. In this sense, a teaching is claimed in which prime training on information in order to create learning situations that facilitate a subsequent continuous training. An active and plural teaching, based on an ongoing investigation, participant in an open, flexible and dynamic disciplinary discourse. It is claimed a teaching that shows a research attitude as a method, both $f$ or the transmission of effective knowledge to the development of capabilities, so that enables the student a more critical and deep intellectual development that trained him to generate new knowledge.

\subsection{New aspects in the university evaluation}

This new university teaching scenario is necessary to rethink the existing assessment processes, which are going to be affected by strong changes. And, not only had the traditional emphasis on the teaching and the teacher, the importance is given today to learning and student as the centre of this learning process, but also changes the evaluation's object, from a series of more complex academic knowledge to the development of skills and the acquisition of basic and applied knowledge [7], but above all changes the role that evaluation has in improving these learning processes.

In this new context, it should encourage autonomous and self-regulated learning verifiable through a continuous and formative assessment [8]. In this way, the usefulness of the evaluation is not only in the ability that it gives us to check the final performance of the student learning but also should serve as a training element, which is integrated into the teaching and learning processes, from beginning to end, forming part of them intending to regulate them, redirect them and improve them while they take place. This process of self-regulation will help students to continue learning throughout life. 
This review in depth of the evaluation process also passes through thinking about how and the agents involved in the evaluation. So, against the punitive nature of traditional evaluation, carried out by the teacher who evaluated a group of students in an exercise of authority, inhibiting the students to make judgments about their own performance, making it impossible to develop the ability to think for themselves or evaluate what they are learning, it is necessary to think about alternatives that involve and engage students in their own evaluation process and therefore, in their own training, in order to achieve a lasting learning that will serve throughout their lifetime.

In this new evaluation model, who evaluates is not only the teacher, but also all those who are involved have a responsibility to participate in the activities of evaluation and self-assessment. Thus, evaluating is a shared responsibility in which neither teaching nor learning stop. The student must participate in all activities to keep learning. Student participation in the evaluation process is an improvement in their learning and skills, as it helps to involve students in their training process and participation in decision-making [9].

In this sense, the evaluation should be understood as a formative and shared activity between teachers and learners. This will allow us to know permanently if the teaching objectives, the methodology, resources, assessment... are responding as expected or they have to be changed in time to get closer to the set goals. It lets us know the learning styles and the quality of them, detect problems both individual and group learning and make adjustments or changes needed. And at the end of each phase of the educational process, issuing a series of value judgments to make jointly (teachers and learners) an overall assessment of the quality of curriculum design. All of this leads us to consider and take into account in the process of teaching-learning not only the most technical aspect of evaluation, but also its more human dimension, critical, reflective, educational and negotiating.

\section{TRAINING AND SHARED ASSESSMENT}

New trends in university teaching bet for a model closely linked to the concept of formative and shared assessment evaluation [10]. In contrast to traditional methods [11], [12] y [13].

Formative assessment refers to the evaluation systems whose main purpose is to improve the teaching and learning process, favouring the autonomous learning of the college student [14], [15] y [16], beyond the mere qualifier objective [17]. Integrate evaluation into the process of teaching and learning, it is to make it a significant activity and requires the involvement of all agents involved.

Meanwhile, shared assessment is based on student participation in the evaluation process, through dialogue and mutual and / or collective decision-making. Thus, evaluation is not something that only affects teachers. While it is true that requires the teacher to student assessment for guidance and orientation for learning, the involvement of students in the evaluation process is also necessary. It is "a learning opportunity for all those involved" [18].

Formative and shared assessment is closely related with active learning methodologies and processes student-centred, their attitudes and values fundamental to the development of certain professional competencies. This affects positively: 1) The improvement and involvement of students in their own learning process. 2) The development of critical thinking, self-criticism and autonomy of the students. Students reflect on their own learning process, taking responsibility of it and becoming aware of the quality of their work. 3) Improves and optimizes the processes of teaching and learning, while helping to correct problems or deficiencies that arise in the development of this process. 4) It is a learning experience in itself. 5) Set one of the most logical systems for learning models focused on the student learning and in the developing of personal and professional skills. 6) In addition, several studies have indicated that this type of evaluation systems favour the improvement of learning outcomes, as well as success rates and academic performance, without entailing an excessive workload as important as it is believed [19].

In the formative and shared assessment, feedback during the process, reflection and the application, among others, of self-assessment techniques, peer assessment, dialogued grades, are extremely useful and play a key role in the learning process [20]. 


\section{METHODOLOGY. AN SPECIFIC PROPOSAL OF FORMATIVE EVALUATION AND SHARED TRAINING AT UNIVERSITY}

Then it is collected the experience about the development of a generic proposal for the design and development of formative evaluation and shared training systems for the university teaching in the architecture degree at the Architectural Projects subject. This teaching proposal aims to respond to the challenges of teaching Architecture today.

In the developing of this proposal the two aspects that are considered most important are: 1 . The use of the evaluation in order to improve teaching - learning processes. 2. The involvement of the students in the evaluation process. In this sense, we have sought a clear alternative to traditional evaluation models only directed to the students qualification.

Then the training activities and the evaluation system conducted by teachers and students in the context of Project Workshop are as follows:

\subsection{Training activities}

During the course of the Project Workshop subject various training activities aimed at encouraging greater participation of the students in their own training are developed. The objective is that they begin to acquire a wealth of knowledge and an optimal training for their initiation into the projecting process. These training activities are as follows:

\subsubsection{Theoretical classes}

In the development of the course seeks to minimize the theoretical classes, being its development parallel to the progress of the works made by the student.

\subsubsection{Practices}

The practices intend to introduce students to the projecting task. Among the objectives pursued in these practices is that the students start to develop, in full intellectual and creative freedom, their faculties as architects and get to express the projecting process coherently.

\subsubsection{Exhibitions, critical sessions, debates and seminars}

In the development of the course are carried out different training activities aimed to promote the active participation of the students in their training

\subsubsection{Teaching activities without presence of the teacher}

As training activities are also contemplated, in addition, individual and/or group non-presential activities which support the learning carried out in the Virtual Classroom enabled in the platform offered by the University.

\subsubsection{Academic Tutorials}

Throughout the course the development of tutorials, regular meetings individual and/or in group between teachers and students are contemplated.

\subsection{Evaluation systems and criteria}

The evaluation system used in the development of this subject is a continuous and comprehensive evaluation based on class attendance, participation in training activities proposed (debates, critical sessions, seminars, courses, conferences ...) and monitoring, presentation and qualification of the listed practices. It takes into account the degree of achievement of the objectives outlined in the subject programme and the competences both transversals and specifics, acquired by the student. So the whole process of both individual and collective learning and not just the result of the final product of each student is evaluated separately.

The fact that has been used continuous assessment is because we believe that it is the best system to exercise and evaluate the acquisition of skills of this subject. This allows students to put into practice the competences that they have to develop, using evaluation to improve, to learn more and better, and not as a final control of their learning towards their qualification. It also allows a more rational 
distribution of the student's workload throughout the semester. This makes that the performance obtained by the student is superior and suppose a personalized monitoring of their learning process.

We have done this continuous evaluation system co-exist with other systems of formative assessment as it is self-evaluation.

\subsubsection{Evaluation Agents}

Evaluation agents have been: teachers, students (self-evaluation) and students (co-evaluation). Thus, it has sought to encourage the active participation of students in their own assessment and evaluation of their peers. This type of evaluation is considered especially interesting for working in group, which need to be constantly monitored and evaluated both by teachers and by its members, in order to go to outlining what actions are useful, appropriate, and effective for achieving the academic, emotional and personal objectives.

For cases of co-evaluation and self-evaluation, in any of them, it has given to the student full responsibility when issuing the final grade. This commitment or it has fallen only in the teachers, or has been made in dialogue.

It has carried out a continuous and formative assessment, practiced throughout all the training process of the students, as well as diverse and shared that involves the students actively, through techniques such as peer assessment or self-assessment in such a way that promotes their evaluation capacity in order to take decisions and direct their own learning process capacity. In the development of this assessment, rubrics have been established in order to provide the students with a simple, clear and concise tool of the aspects to be evaluated, by clearly defining the evaluation criteria and the different levels which are taken into account.

This assessment system defines a process of teaching and learning that focuses on the student autonomy and responsibility to guide and manage it. It has been searched a route to a formative evaluation process that leads students to adopt a critical perspective on the learning process. Evaluate is considered an educational activity, since the time spent assessing is a time dedicated to learning.

\subsubsection{Evaluation criteria}

In a teaching project geared more to teach an attitude, a disposition towards the project, to create learning situations aimed at the training of the students rather than the accumulation of objectified knowledge, it seems appropriate to consider as evaluation criteria, attitudes and media that highlight and promote the student learning experience.

- Teaching project requires the continued support and participation of teachers and students in the proposed activities. A minimum of $85 \%$ attendance at classes is required.

- The finding of content mastery, theoretical and practical and the critical preparation thereof is valued.

- It is assessed the degree of involvement and the attitude of the students expressed in their active participation and contribution to the collective education of teachers and students in the course development; as well as in the elaboration of individual or in group practices, in the latter the consensus and interaction with the group are valued.

- It is assessed the critical disposition of the students to acquire knowledge and self-critical attitude towards their own work.

- The attitude of perseverance and continuous student work is evaluated, as well as their positive disposition towards learning.

- The final evaluation of the course arises from the consideration of the advance and student progress along it as well as the achievement of the objectives that have been set in each of the proposed activities.

- The quality of the work performed individually or team basis is valued.

- It is considered essential for the positive evaluation of the student the monitoring, development and delivery of various activities in the time and manner established in the subject's Program. 


\section{ANALYSIS OF THE RESULTS}

In the development of this educational proposal it has been warned as this it is innovative for most students. Many of them expressed satisfaction in participating in the evaluation, discuss the proposals and take decisions. For many, this proposal sheds transparency in the evaluation process and considered the fairest way to assess, as they are participants in their final grade.

It has been found that, through this formative and shared assessment proposal, the students learn to self-assess and evaluate the others. They identify the weaknesses that must be strengthened and shortcomings that should correct, to regulate and adapt themselves to the demands of the course, assuming their own responsibility, both in their learning process as the rest of the class. Also, it has been notice a greater involvement and motivation, further development of autonomy by students and improved ratings in this continuous learning and training way, than in the traditional systems.

In the beginning of this teaching proposal, it was noted in most of the student body some discomfort, perhaps the result of a certain immaturity, when evaluating their peers, and indicating that this implied a responsibility that sometimes could generate a contentious episode. This attitude changed when it came to evaluating themselves. It follows, therefore, that students are not sufficiently prepared for this practice, since it is an evaluation system that is not very common, but which, however, gradually students begin to add, making responsible use.

The final assessment by the students of this evaluation system has been positive since, even though it is aware of the workload and time to devote to the pursuit of the subject, assesses this as something positive. The students are learning and perceive that their effort is worth it.

\section{CONCLUSIONS}

Formative evaluation and shared teaching is a major challenge that brings us closer to the approach of the EHEA. This integrative assessment affects the quality of teaching and training of the students, improving the teaching and the learning processes that we undertake.

This evaluation system has proved useful in facilitating and increasing the involvement of the students in their own training, promoting independent learning. It also promotes active participation and the development of self-criticism in the students. This makes that they feel responsible for their own learning. This degree of involvement that assumes the student in the process and achievement of higher levels of learning attached to the development of a more constant work throughout the course make that failure and abandonment rates are lower than those obtained with traditional teaching and evaluation methods.

This evaluation system requires, however, deal with the initial resistance that both students and teachers show as they have internalized models and traditional habits of assessment. It is also necessary to clarify that, although it seems that the relative workload increases for both students and teachers, with this evaluation system it is more distributed throughout all the process, as it is distributed in a more uniform way during the course compared to the traditional teaching models.

\section{REFERENCES}

[1] C. Florido; J. L. Jiménez and I. Santana, "Obstáculos en el camino hacia Bolonia: efectos de la implantación del Espacio Europeo de la Educación Superior (EEES) sobre los resultados académicos," Revista de Educación, núm. 354, pp. 629-656, 2008.

[2] M. B. Álvarez, "Adaptación del método docente al Espacio Europeo de Educación Superior: La motivación de los alumnos como instrumento clave," Estudios sobre Educación, núm. 9, pp. 107-126, 2005.

[3] E. Chocarro; M. C. González and A. Sobrino, "Nuevas orientaciones en la formación del profesorado para una enseñanza centrada en la promoción del aprendizaje autorregulado de los alumnos," Estudios sobre Educación, núm. 12, pp. 81-98, 2007.

[4] F. Dochy; M. Segers and S. Dierick, "Nuevas vías de aprendizaje y enseñanza y sus consecuencias: una nueva era de evaluación," Boletín de la Red Estatal de Docencia Universitaria, 2 (2), pp. 12-31, 2002. 
[5] M. de Miguel, Modalidades de enseñanza centradas en el desarrollo de competencias. Oviedo: Universidad de Oviedo, 2005.

[6] T. Anasagasti, Enseñanza de la Arquitectura: cultura moderna técnico artística. Madrid: Sucesores de Rivadeneyra, 1923.

[7] A. Gessa, "La coevaluación como metodología complentaria de la evaluación del aprendizaje. Análisis y reflexión en las aulas universitarias," Revista de Educación, núm. 354, pp. 749-764, 2011.

[8] V. López; L. F. Martínez and J. A. Julián, “La Red de Evaluación Formativa, Docencia universitaria y Espacio Europeo de Educación Superior. Presentación del proyecto, grado de desarrollo y primeros resultados," Revista de Docencia Universitaria, 2, pp. 1-19, 2007.

[9] V. López, "Evaluación formativa y compartida en la universidad: clarificación de conceptos y propuestas de intervención desde la Red Interuniversitaria de Evaluación Formativa," Psychology, Society, \& Education, Vol. 4, núm. 1, pp. 117-130, 2012.

[10] F. Buscá; P. Pintor; L. Martínez and T. Peire, "Sistemas y procedimientos de Evaluación Formativa en docencia universitaria: resultados de 34 casos aplicados durante el curso académico 2007-2008," Estudios sobre Educación, Vol. 13, pp. 255-276, 2010.

[11] M. Zabalza, La enseñanza universitaria: el escenario y sus protagonistas. Madrid: Narcea Ediciones, 2002.

[12] J. Álvarez, La evaluación a examen. Ensayos críticos. Madrid: Miño y Dávila Editores, 2003.

[13] M. Bonsón and A. Benito, "Evaluación y Aprendizaje" in Nuevas claves para la docencia universitaria en el Espacio de Educación Superior (A. Benito and A. Cruz, eds.), pp. 87-100, Madrid: Narcea, 2005.

[14] S. Brown and A. Glasner, Evaluar en la universidad: problemas y nuevos enfoques. Madrid: Narcea Ediciones, 2003.

[15] A. Delgado; R. Borge; J. García; R. Oliver and L. Salomón, Competencias y diseño de la evaluación continua y final en el Espacio Europeo de Educación Superior. Programa de Estudios y análisis de la Dirección General de Universidades del Ministerio de Educación y Ciencia, 2005.

[16] L. Villardón, "Evaluación del aprendizaje para promover el desarrollo de competencias," Educación Siglo XXI, núm. 24, pp. 57-76, 2006.

[17] A. Pérez; J. A. Julián and V. López, "Evaluación formativa y compartida en el Espacio Europeo de Educación Superior (EEES)" in Evaluación formativa y compartida en educación superior (V. López, coord.), pp. 19-43, Madrid: Narcea, 2009.

[18] A. Bretones, "La participación del alumnado en la evaluación de sus aprendizajes," Kikiriki, vol. 65, pp. 6-15.

[19] V. López, "Good practice on Superior Educatio Evaluation: a Case of Formative and Sharing Evaluation," Journal of Technology and Science Education, 1 (2), pp. 1-12, 2011.

[20] V. López, "El papel de la Evaluación Formativa en el proceso de una Convergencia hacia el EEES. Análisis del estado de la cuestión y presentación de un sistema de intervención," Revista Interuniversitaria de Formación del Profesorado, 57, Vol. 20-3, pp. 93-120, 2006. 